\title{
Fish-mediated nutrient recycling and the trophic cascade in lakes
}

\author{
José Luiz Attayde and Lars-Anders Hansson
}

\begin{abstract}
The effects of planktivorous fish on phytoplankton through nutrient recycling and zooplankton herbivory were experimentally separated and their relative importance quantified in a eutrophic humic lake. Natural phytoplankton assemblages were incubated in nutrient-permeable chambers placed inside enclosures with or without fish. Outside these chambers, phytoplankton were exposed to zooplankton herbivory and to nutrient recycling by fish and zooplankton, whereas inside the chambers, phytoplankton were exposed only to nutrient recycling by these consumers. Our results show that fish had significant positive effects on cyanobacteria, cryptomonads, and chlorophytes inside the chambers, indicating that fish-mediated nutrient recycling had significant effects on these phytoplankton groups. However, our results also indicate that changes in zooplankton grazing induced by fish were an important mechanism by which fish affected all phytoplankton groups except cyanobacteria. Comparison of effect sizes revealed that the effects on cyanobacteria and chlorophytes through nutrient recycling were stronger than those through zooplankton grazing. Moreover, most of the fish-mediated nutrient recycling effects were due to increased nutrient recycling by zooplankton rather than direct nutrient excretion by fish. In conclusion, we provide experimental evidence supporting the hypothesis that fish-mediated nutrient recycling is an important mechanism affecting phytoplankton community structure and favoring cyanobacteria dominance in lakes.
\end{abstract}

Résumé : Les effets des poissons planctonophages sur le phytoplancton par le biais du recyclage des éléments nutritifs et l'herbivorie du zooplancton ont pu être séparés expérimentalement et leurs importances relatives quantifiées dans un lac humique eutrophe. Des peuplements naturels de phytoplancton ont été mis en incubation dans des contenants perméables aux nutriments placés dans des enceintes avec ou sans poissons. À l'extérieur des contenants, le phytoplancton était exposé à l'herbivorie du zooplancton et au recyclage des éléments nutritifs par le zooplancton et les poissons, alors que, dans les contenants, le phytoplancton était exposé seulement au recyclage des nutriments par ces consommateurs. Nos résultats indiquent que les poissons ont des effets positifs sur les cyanobactéries, les cryptomonadines et les chlorophytes à l'intérieur des contenants, ce qui montre que le recyclage des nutriments généré par les poissons a des effets significatifs sur ces groupes phytoplanctoniques. Cependant, nos résultats indiquent aussi que le broutage du zooplancton sous l'effet des poissons est un mécanisme significatif par lequel les poissons affectent les groupes phytoplanctoniques, à l'exception des cyanobactéries. Une comparaison des importances relatives des effets montre que les conséquences sur les cyanobactéries et les chlorophytes du recyclage des nutriments sont plus grandes que celles du broutage du zooplancton. De plus, la plupart des effets dus au recyclage des éléments par l'action des poissons sont occasionnés par un recyclage accru des nutriments par le zooplancton, plutôt que par une excrétion directe de nutriments par les poissons. En conclusion, on trouve ici des preuves expérimentales que le recyclage des nutriments par l'action des poissons est un mécanisme important qui affecte la structure de la communauté phytoplanctonique et qui favorise la dominance des cyanobactéries dans les lacs.

[Traduit par la Rédaction]

\section{Introduction}

It has been well demonstrated in lakes that planktivorous fish selectively consume large zooplankton, shift zooplankton communities toward dominance by smaller species or

Received November 15, 2000. Accepted June 14, 2001.

Published on the NRC Research Press Web site at

http://cjfas.nrc.ca on September 7, 2001.

J16066

J.L. Attayde. ${ }^{1}$ Departamento de Oceanografia e Limnologia, Universidade Federal do Rio Grande do Norte, Praia de Mae Luiza s/n, Via Costeira, 59014-100, Natal, RN, Brazil.

L.-A. Hansson. Department of Limnology, Institute of

Ecology, Lund University, Ecology Building, S-223 62, Lund, Sweden.

${ }^{1}$ Corresponding author (e-mail: attayde@dol.ufrn.br). individuals (reviewed by Gliwicz and Pijanowska 1989), increase phytoplankton biomass and productivity (Carpenter and Kitchell 1993), and often change phytoplankton communities toward dominance by cyanobacteria (e.g., Reinertsen et al. 1986; Starling and Rocha 1990; Vanni and Findlay 1990). Several enclosure and whole-lake experiments have shown that reduced stocks of planktivorous fish may cause decreases in both algal biomass and dominance of cyanobacteria (e.g., Reinertsen et al. 1990; Vanni and Findlay 1990), and many attempts have been made to improve the water quality of eutrophic lakes through removal of fish (e.g., Gulati et al. 1990; Hansson et al. 1998; Hansson and Bergman 1999). Although the effects of planktivorous fish on phytoplankton have been well demonstrated, the relative importance of the mechanisms accounting for these effects are still not clear.

Several previous studies have shown that large-bodied zooplankton generally have higher mass-specific grazing rates 
than small zooplankton and can effectively graze a broader range of size-classes and morphologies of phytoplankton (reviewed by Sterner 1989). Therefore, planktivorous fish can reduce zooplankton grazing on phytoplankton by decreasing zooplankton size structure, and this can potentially explain the positive response of phytoplankton to fish. However, several enclosure and whole-lake experiments have demonstrated that the effects of planktivorous fish on phytoplankton cannot be explained by variations in zooplankton grazing alone (Vanni and Findlay 1990; Schindler 1992; Vanni and Layne 1997). Moreover, colonial or filamentous cyanobacteria are highly resistant to zooplankton grazing, and there is reason to doubt that their positive response to planktivorous fish is due to reduced zooplankton grazing.

By changing zooplankton species composition and size structure, planktivorous fish can also affect the rates and ratios by which zooplankton recycle nutrients to phytoplankton. Because small-bodied zooplankton have higher mass-specific rates of nutrient recycling than large zooplankton (reviewed by Sterner 1989), an assemblage dominated by small zooplankton should recycle nutrients at higher rates than an assemblage of equal biomass dominated by large zooplankton (Carpenter and Kitchell 1993). Therefore, planktivorous fish may indirectly increase nutrient recycling rates by zooplankton, if total zooplankton biomass is not reduced by fish (Ramcharan et al. 1996). Moreover, large cladocerans like Daphnia have higher $\mathrm{P}$ and lower $\mathrm{N}$ demand than smaller cladocerans and copepods and may release nutrients at higher N:P ratios (Sterner et al. 1992; Sterner and Hessen 1994). Because the N:P supply ratio can have strong effects on phytoplankton community structure and dynamics (reviewed by Sommer 1989), shifts in this ratio driven by fish may have important effects on phytoplankton communities (Attayde and Hansson 1999). In particular, fish might decrease the N:P ratio released by zooplankton (Sterner et al. 1992) and thereby favor cyanobacteria, which have a strong competitive advantage under low N:P ratios (Smith 1983).

Planktivorous fish can also affect phytoplankton communities by directly releasing nutrients through excretion and defecation (Vanni and Findlay 1990; Schindler 1992; Vanni and Layne 1997). Nutrient excretion by fish has long been considered an important source of nutrients to phytoplankton (Lamarra 1975), and some studies have shown that fish can recycle nutrients at rates exceeding external nutrient loading rates (Braband et al. 1990; Reinertsen et al. 1990; Persson 1997). Since fish release nutrients at low N:P ratios (Braband et al. 1990; Schindler and Eby 1997; Attayde and Hansson 1999), they might also favor cyanobacteria directly by their own waste products. In addition, the pulsed release of nutrients from fish contrary to zooplankton may favor the uptake kinetics of cyanobacteria (Reinertsen et al. 1986).

Hence, planktivorous fish can affect the structure and dynamics of phytoplankton communities through both zooplankton grazing and nutrient recycling mechanisms. However, the extent to which different algal groups respond to fish-mediated nutrient recycling effects and whether these effects are more important than those through zooplankton herbivory is unclear. Here, we present results of a press perturbation experiment in a Swedish lake designed to examine the relative importance of these mechanisms. Our approach was to measure the effect size of fish on the net changes in algal biovolume during the experiment. With such an approach, the relative importance of each mechanism was ascertained by comparing the magnitude of one effect relative to that of the other. We demonstrate that fish effects on cyanobacteria and chlorophytes through nutrient recycling can actually be more important than those through zooplankton grazing. Our results also suggest that most of the fish-mediated nutrient recycling effects were due to fish-induced effects on nutrient recycling by zooplankton.

\section{Material and methods}

\section{Study site}

The experiment was conducted in Dagstorpssjön, a eutrophic and humic lake situated in the middle of Scania, southern Sweden. The lake area is $0.48 \mathrm{~km}^{2}$, maximum depth is $5 \mathrm{~m}$, and mean depth is $2.8 \mathrm{~m}$. Perch (Perca fluviatilis) is the most important species of fish in the lake and can have strong effects on zooplankton and phytoplankton dynamics (Romare et al. 1999). During our experiment, the concentrations of chlorophyll $a$ and total $\mathrm{P}$ in the lake ranged from 29 to $77 \mu \mathrm{g} \cdot \mathrm{L}^{-1}$ and from 39 to $47 \mu \mathrm{g} \cdot \mathrm{L}^{-1}$, respectively, while the dissolved organic $\mathrm{C}$ concentration ranged from 8.78 to $9.54 \mathrm{mg} \cdot \mathrm{L}^{-1}$. At the start of the experiment, the phytoplankton community in the lake was dominated by cyanobacteria, while rotifers dominated the zooplankton community.

\section{Experimental design}

The experiment was conducted from August 12 to September 10, 1997. Two treatments were employed with four replicates: a control treatment containing natural plankton densities with no addition of fish and a fish treatment containing natural plankton densities plus three perch ( $P$. fluviatilis) about $8 \mathrm{~cm}$ long. Inside each enclosure, we placed nutrient-permeable chambers of approximately $0.63 \mathrm{~m}^{3}$ (made of a $10-\mu \mathrm{m}$-mesh net) where natural phytoplankton assemblages were incubated, after screening $300 \mathrm{~L}$ of lake water through a $100-\mu \mathrm{m}$-mesh net to remove large zooplankton. Inside these chambers, phytoplankton were exposed to nutrient recycling by zooplankton and fish but not to herbivory from zooplankton larger than $100 \mu \mathrm{m}$, while outside the chambers, phytoplankton were exposed to both zooplankton herbivory and nutrient recycling by these consumers. This experimental design is similar to the design of Vanni and Layne (1997), but our chambers had a mesh size twice as large and held a volume 10 times greater than the chambers used by Vanni and Layne (1997). Because the chambers allowed phytoplankton cells smaller than $10 \mu \mathrm{m}$ to pass through and because the filtration before incubation removed algae larger than $100 \mu \mathrm{m}$, we only include the response of taxa with greatest axial linear dimension larger than $10 \mu \mathrm{m}$ and smaller than $100 \mu \mathrm{m}$ in our estimates of phytoplankton response to fish.

Enclosures were made of thin, clear polyethylene formed into a cylindrical tube and suspended from a wooden frame buoyed by styrofoam floats. Enclosures were sealed at the bottom and open to the atmosphere at the top. The diameter of the enclosures was $1.6 \mathrm{~m}$ and the depth was $1.5 \mathrm{~m}$, yielding a volume of approximately $3 \mathrm{~m}^{3}$. The diameter of the chambers was $0.4 \mathrm{~m}$ and the depth was $0.5 \mathrm{~m}$, yielding a volume of approximately $0.63 \mathrm{~m}^{3}$. Twice a week, the enclosures and the chambers were brushed to avoid colonization by periphyton on the walls and carefully checked for dead fish, since decaying fish could affect the outcome of the experiment (Threlkeld 1987). No fish died during the experiment.

The fish stocking rate used in our experiment (about $70 \mathrm{~kg} \cdot \mathrm{ha}^{-1}$ ) was a reasonable amount of fish for a lake with total P concentrations of aproximately $40-50 \mu \mathrm{g} \cdot \mathrm{L}^{-1}$ (Hanson and Leggett 1982). 
Fig. 1. Schematic representation of the experimental design and the mechanisms assessed in this study.

\section{Experimental design}

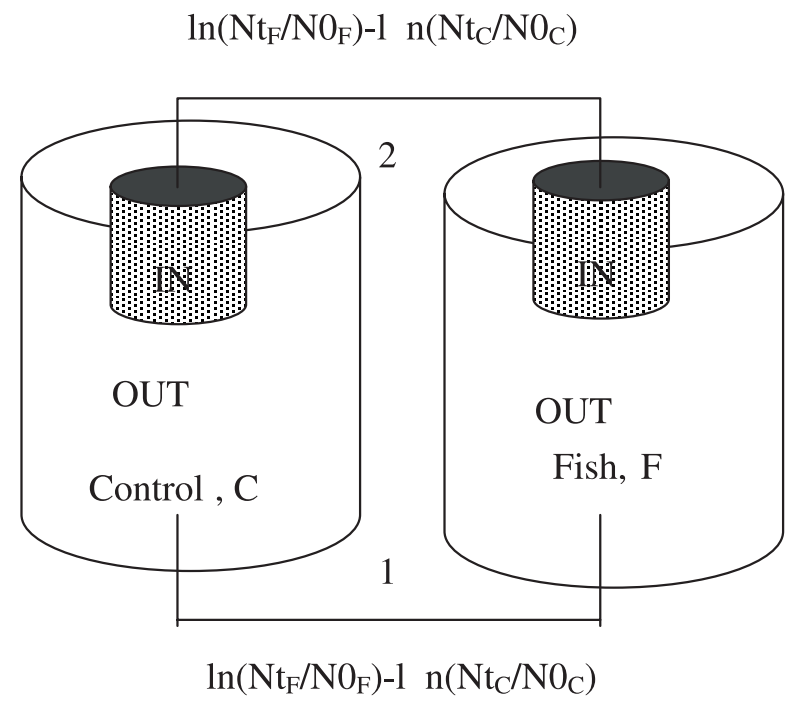

- 1) Total effect of fish

- 2) Fish effect through nutrient recycling from both zooplankton and fish

- $1-2$ = Fish effect through zooplankton herbivory

Fish were also fed with $3 \mathrm{~g}$ (wet weight) of chironomid larvae every 3 days and the same amount of chironomids was added to the control to avoid biased enrichment of the fish treatment. This amount of chironomids constituted a ration size of approximately $2 \%$ of the fish weight per day. We added chironomids because many planktivorous fishes under natural conditions, including the $1+$ perch used in our experiment, also eat benthic prey and excrete nutrients from benthic habitats into pelagic habitats, which may have important consequences for planktonic communities (Schindler et al. 1996; Vanni 1996; Schaus and Vanni 2000).

\section{Sampling and counting}

Phytoplankton samples were collected at the beginning, middle, and end of the experiment (days 1, 14, and 28, respectively) from both outside and inside the chambers of each enclosure and were preserved with acid Lugol's solution. Algae were counted at 250x magnification on permanent slides made using HPMA (Crumpton 1987). In each sample, a minimum of 10 fields or 200 cells were counted. The length and width of 20 individuals of each algal species were measured and the biovolumes were calculated using different formulae according to their geometric shape (Tikkanen and Willén 1992).

Zooplankton samples were also taken from outside the chambers, filtered through a $10-\mu \mathrm{m}$-mesh net to concentrate the organisms, and preserved with acid Lugol's solution. Organisms were counted at $100 \times$ magnification with an inverted microscope, after sedimentation in $10-\mathrm{mL}$ chambers for at least $2 \mathrm{~h}$. At least 200 organisms of each group were counted per zooplankton sample. For each zooplankton sample, the length of 20 individuals of each taxon was measured and the respective biomass calculated using specific length-weight regression equations reported in Dumont et al. (1975) and Bottrell et al. (1976). The biomass of each taxon in
Fig. 2. Mean biomass of total zooplankton and the relative importance of rotifers, cladocerans, and copepods in the fish and control treatments after $(a) 1$ day, $(b) 14$ days, and (c) 28 days from the start of the experiment.

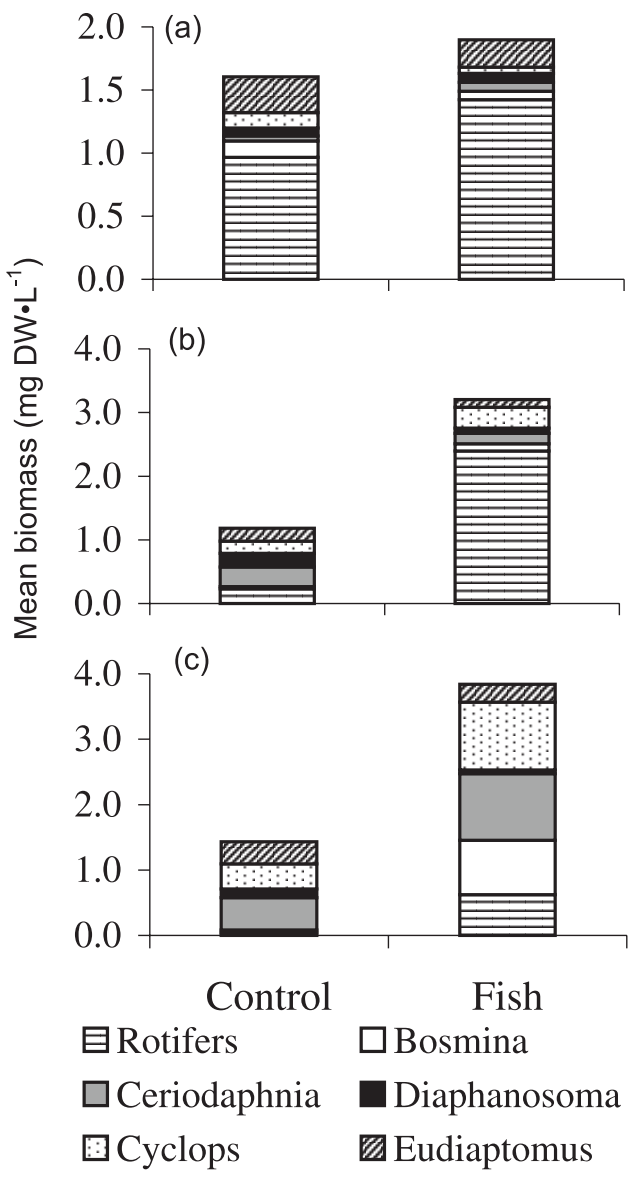

a given sample was estimated as the product of its mean biomass and density in that sample. Total zooplankton biomass was estimated as the sum of the total biomass of rotifers, cladocerans, and copepods.

\section{Data analysis}

The total effect of fish on phytoplankton was assessed as the difference between the net changes in algal biovolume outside the chambers of the fish and control treatments (Fig. 1). The effect of fish on phytoplankton through nutrient recycling was assessed as the difference between the net changes in algal biovolume inside the chambers of the fish and control treatments (Fig. 1). The difference between the fish effects outside and inside the chambers was used as an estimate of the fish effect on phytoplankton through zooplankton grazing (Fig. 1). Hence, the magnitude of the fish effect on phytoplankton outside or inside the chambers was estimated as $\ln \left(N_{t, \mathrm{~F}} / N_{0, \mathrm{~F}}\right)-\ln \left(N_{t, \mathrm{C}} / N_{0, \mathrm{C}}\right)$ where $t$ is the duration of the experiment (14 or 28 days) and $N_{t, \mathrm{~F}}$ and $N_{t, \mathrm{C}}$ (or $N_{0, \mathrm{~F}}$ and $N_{0, \mathrm{C}}$ ) are the algal biovolume at $t$ days (or at the start) of the experiment in the fish and control treatments, respectively (modified from Osenberg et al. 1997). The ratios of abundances $\left(N_{t} / N_{0}\right)$ were log transformed before the effect size metric was calculated to stabilize variances in the effect size data as well as provide a symmetrical scale. In order to express the full range of variation in our experiment, the effect of fish outside or inside the chambers was calculated for each replicate of the fish treatment as the change relative 
Fig. 3. Mean ( $\pm 1 \mathrm{SD})$ biovolume of $(a)$ total phytoplankton, $(b)$ cyanobacteria, $(c)$ cryptomonads, $(d)$ diatoms, and $(e)$ chlorophytes outside and inside the chambers of the fish and control treatments after 1, 14, and 28 days from the start of the experiment. Control out, grey bars; fish out, open bars; control in, solid bars; fish in, hatched bars.
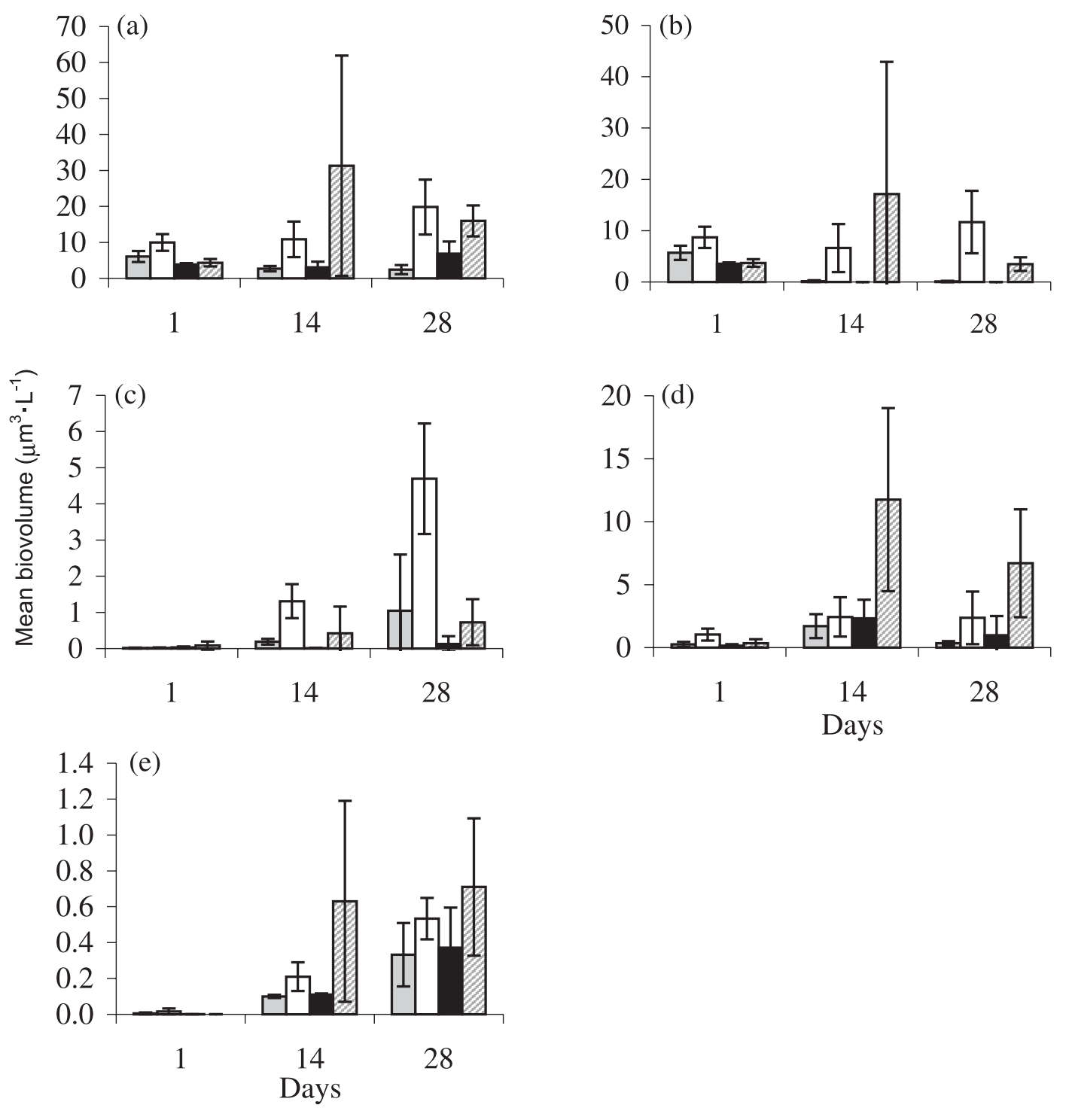

to each control replicate $(4 \times 4$ replicates $=16$ effect size estimates). From these distributions of effect size, we calculated the mean and standard deviation of each fish effect.

A $t$ test was used to test for differences between treatment effects on the net changes in algal biovolume. A significant difference between the changes in algal biovolume outside the chambers of the fish and control treatments indicates that the total effect of fish was significantly different from zero $\left(\ln \left(N_{t, \mathrm{~F}} / N_{0, \mathrm{~F}}\right) \quad-\right.$ $\left.\ln \left(N_{t, \mathrm{C}} / N_{0, \mathrm{C}}\right) \neq 0\right)$. Likewise, a significant difference between the changes in algal biovolume inside the chambers of the fish and control treatments indicates that the effect of fish through nutrient recycling mechanisms was significantly different from zero. A paired-sample $t$ test was used to test for differences between the fish effects on phytoplankton outside and inside the chambers. Here, the null hypothesis was that the effects of fish through nutrient recycling (inside) were not significantly different from the total effect of fish (outside). Since statistical significance does not measure the biological importance of a factor or mechanism, the relative importance of the fish effects through zooplankton herbivory

Table 1. Mean and SD of total zooplankton biomass in the control (C) and fish (F) treatments after 1, 14, and 28 days from the start of the experiment.

\begin{tabular}{cllll}
\hline Days & Mean C & SD C & Mean F & SD F \\
\hline 1 & 1.64 & 0.38 & 1.91 & 0.14 \\
14 & 1.28 & 0.23 & 3.28 & 1.72 \\
28 & 1.51 & 1.16 & 3.96 & 0.49 \\
\hline
\end{tabular}

and nutrient recycling mechanisms was ascertained by comparing the effect size of one factor relative to that of the other.

\section{Results}

At the start of the experiment, the zooplankton community was dominated by rotifers (Fig. 2), while the phytoplankton community was dominated by cyanobacteria in 
Table 2. Mean and SD of the net change in biovolume of the major taxonomic groups inside and outside the chambers of the control (C) and fish (F) treatments after 14 and 28 days from the start of the experiment and results of the $t$ test $(\mathrm{df}=6)$ for differences between treatment effects on algal biovolume changes.

\begin{tabular}{|c|c|c|c|c|c|c|c|c|c|c|c|c|}
\hline & \multicolumn{6}{|l|}{ Inside } & \multicolumn{6}{|l|}{ Outside } \\
\hline & Mean C & $\mathrm{SD} \mathrm{C}$ & Mean F & SD F & $t$ & $p$ & Mean C & $\mathrm{SD} \mathrm{C}$ & Mean F & SD F & $t$ & $p$ \\
\hline \multicolumn{13}{|l|}{ Day 14} \\
\hline Cryptomonads & -0.16 & 0.13 & 0.27 & 1.71 & -0.49 & 0.32 & 0.80 & 0.67 & 2.44 & 0.38 & -4.24 & $<0.01$ \\
\hline Cyanobacteria & -3.59 & 0.07 & 0.24 & 2.09 & -3.66 & 0.01 & -3.39 & 0.72 & -0.48 & 0.82 & -5.31 & $<0.01$ \\
\hline Chlorophytes & 0.68 & 0.39 & 1.63 & 1.02 & -1.75 & 0.07 & 0.60 & 0.42 & 0.87 & 0.61 & -0.73 & 0.25 \\
\hline Total algae & 0.47 & 0.61 & 1.29 & 0.30 & -2.40 & 0.03 & -0.99 & 0.61 & 0.66 & 0.28 & -4.92 & $<0.01$ \\
\hline Cryptomonads & 0.30 & 0.66 & 1.43 & 1.17 & -1.68 & 0.07 & 1.54 & 1.56 & 3.68 & 0.28 & -2.71 & 0.02 \\
\hline Cyanobacteria & -3.57 & 0.06 & -0.09 & 0.40 & -17.17 & $<0.01$ & -3.52 & 0.79 & 0.21 & 0.38 & -8.51 & $<0.01$ \\
\hline Chlorophytes & 1.44 & 0.58 & 2.00 & 0.51 & -1.46 & 0.10 & 1.34 & 0.41 & 1.69 & 0.28 & -1.40 & 0.10 \\
\hline Diatoms & 0.76 & 1.96 & 2.45 & 1.28 & -1.44 & 0.10 & 0.29 & 0.83 & 0.49 & 1.28 & -0.26 & 0.40 \\
\hline
\end{tabular}

both treatments (Fig. 3). During the experiment, the total biomass of zooplankton doubled in the fish treatment but remained approximately constant in the control (Fig. 2; Table 1). Fish significantly increased total zooplankton biomass after both 14 days $(t=2.30, p=0.05)$ and 28 days $(t=3.89, p<0.01)$, and this was mainly due to an increase in rotifer biomass after 14 days and an increase in Bosmina, Ceriodaphnia, and Cyclops biomass after 28 days (Fig. 2). The total biovolume of phytoplankton also increased both outside and inside the chambers of the fish treatment but slightly decreased outside the chambers of the control (Fig. 3). The increase in total algal biovolume in the presence of fish was mainly due to an increase in the biovolumes of cyanobacteria, diatoms, and cryptomonads, while the decrease in total algal biovolume in the control was mainly due to a disapearance of cyanobacteria in the absence of fish (Fig. 3).

Outside the chambers, where phytoplankton were exposed to grazing by zooplankton and to nutrient recycling by fish and zooplankton, the biovolume of cryptomonads increased in both treatments $\left(\ln \left(N_{t} / N_{0}\right)\right.$ was positive $)$, but this increase was significantly higher in the fish treatment than in the control (Table 2). On the other hand, the biovolume of cyanobacteria decreased in both treatments after 14 days $\left(\ln \left(N_{t} / N_{0}\right)\right.$ was negative), but this decrease was significantly lower in the fish treatment than in the control (Table 2). Significant positive effects of fish on cyanobacteria were also found after 28 days of experiment (Table 2). Fish also had significant effects on total phytoplankton biovolume during the experiment (Table 2).

Inside the chambers, where phytoplankton were exposed to nutrient recycling by zooplankton and fish but not to grazing by zooplankton larger than $100 \mu \mathrm{m}$, fish had significant effects on total phytoplankton biovolume as well as on the biovolumes of cyanobacteria, chlorophytes, and cryptomonads (Table 2). This clearly indicates that fish had effects on phytoplankton independent of their effects on zooplankton grazing. Furthermore, examining the response of the major phytoplankton genera to fish reveals that fish had significant effects on the biovolume of Microcystis, Scenedesmus, and Snowella both outside and inside the chambers (Table 3), in- dicating that part of their response to fish outside the chambers was actually due to nutrient recycling mechanisms mediated by fish.

Quantifying the magnitude of these fish effects reveals that cyanobacteria had the strongest positive response to fish both outside and inside the chambers. Results of the paired $t$ test show that these responses were not significantly different from each other (Table 4), suggesting that fish effects on cyanobacteria were mainly through nutrient recycling mechanisms. In addition, we found no differences between the fish effects on chlorophytes outside and inside the chambers at the end of the experiment (Table 4), suggesting that fishmediated nutrient recycling can also account for most of the fish effects on chlorophytes. However, the relative importance of the fish effects through nutrient recycling (inside the chambers) and zooplankton herbivory (outside minus inside the chambers) was assessed by comparing the effect size of one mechanism relative to that of the other. Indeed, this comparison indicates that the effects of fish on cyanobacteria and chlorophytes through nutrient recycling were stronger than those through zooplankton herbivory (Table 4). On the other hand, the effects of fish on cryptomonads and diatoms through zooplankton herbivory were stronger than those through nutrient recycling after 14 days but not after 28 days of experimentation (Table 4). After 14 days, fish had stronger effect on total phytoplankton through nutrient recycling, but at the end of the experiment, this effect was of similar magnitude to that through zooplankton grazing (Table 4).

Finally, the effect size estimates show that fish had positive effects on all phytoplankton groups (except diatoms after 14 days) both outside and inside the chambers (Table 4). However, the effects of fish on cryptomonads were stronger outside than inside the chambers, while those on chlorophytes and diatoms were stronger inside than outside the chambers (Table 4). This suggests that fish had positive effects on cryptomonads but negative effects on chlorophytes and diatoms through zooplankton grazing (outside minus inside, Table 4). Results also suggest that the effects of fish on cyanobacteria and total phytoplankton through zooplankton grazing (outside minus inside) were negative after 14 days but positive after 28 days (Table 4 ). 


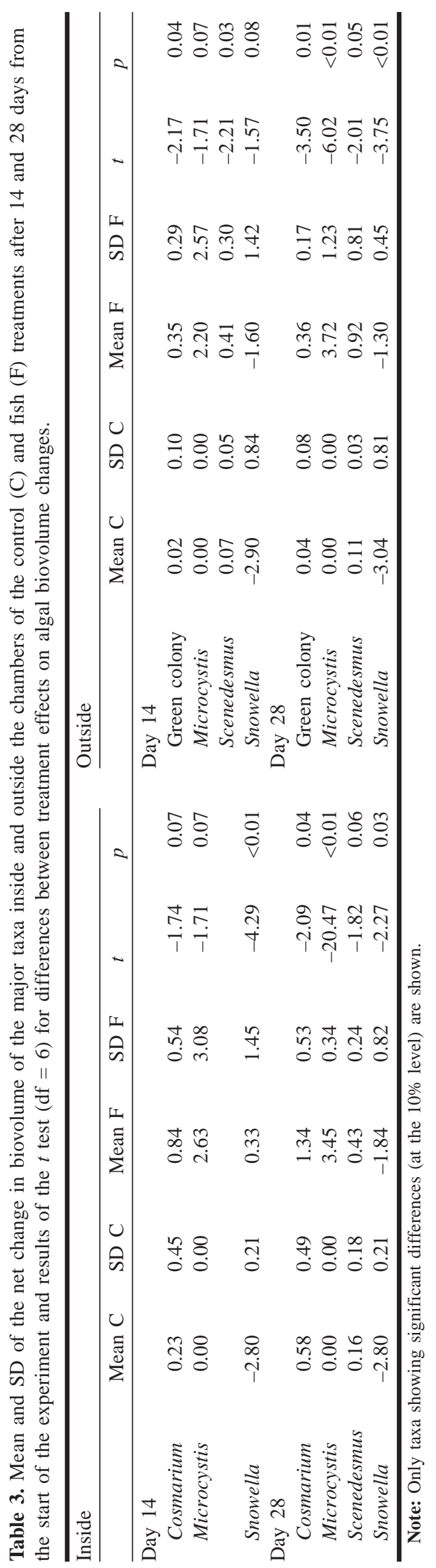

\section{Discussion}

It has been demonstrated repeatedly in lakes that planktivorous fish can have strong effects on the structure and dynamics of planktonic communities (reviewed by Lazzaro 1987). However, the relative importance of the different mechanisms accounting for the effects of fish on phytoplankton is still not clear. It is also unknown which phytoplankton groups exhibit the largest response to nutrient recycling effects mediated by fish. In the present study, we have demonstrated that fish can actually have effects on cyanobacteria and chlorophytes through nutrient recycling that are stronger than their effects through zooplankton grazing. To our knowledge, only two previous studies have experimentally separated and quantified the effects of fish through nutrient recycling on the structure and dynamics of phytoplankton communities (Schindler 1992; Vanni and Layne 1997). Schindler (1992) concluded that nutrient excretion by fish explained most of the fish effects on total algal biomass and suggested that changes in zooplankton grazing were not a very important mechanism by which fish affected phytoplankton. Vanni and Layne (1997) also found that fish had substantial effects on phytoplankton through nutrient recycling, but it is not clear from their results if these effects were more important than those through zooplankton grazing.

Our study suggests that fish-mediated nutrient recycling may account for most of the total phytoplankton response to fish when the phytoplankton community is dominated by cyanobacteria or chlorophytes. This result has important implications for lake management because most attempts to improve the water quality of eutrophic lakes through biomanipulation have been based on the idea that reduced stock of planktivorous fish should lead to increased zooplankton grazing on phytoplankton and thereby reduced phytoplankton biomass and increased water transparency. However, as the phytoplankton communities of eutrophic lakes are often dominated by cyanobacteria and chlorophytes, planktivorous fish removal should affect total phytoplankton biomass mainly through nutrient recycling mechanisms in such lakes.

Obviously, the fact that fish can influence phytoplankton by altering nutrient recycling does not imply that fishinduced changes in zooplankton grazing cannot have important effects on phytoplankton communities. Many studies have shown that zooplankton grazing has strong effects on phytoplankton communities (reviewed by Sterner 1989), and our study also indicates that fish-induced changes in zooplankton grazing had significant effects on all phytoplankton groups except cyanobacteria. Our results show that the effects of fish through nutrient recycling (inside the chambers) were significantly different from the total effect of fish (outside the chambers), suggesting that alterations of zooplankton grazing was an important mechanism by which fish affected phytoplankton.

In our study, we have not separated the two mechanisms by which fish can affect phytoplankton through nutrient recycling: by directly releasing nutrients and by changing the rates and ratios at which zooplankton release nutrients (Vanni and Findlay 1990; Schindler 1992; Vanni and Layne 1997). The only study that has experimentally separated 
Table 4. Mean effect size and SD of the fish effects on algal biovolume outside (OUT) and inside (IN) the chambers excluding mesozooplankton, the difference between the mean effect sizes outside and inside the chambers (OUT $-\mathrm{IN})$, and results of the paired $t$ test $(\mathrm{df}=15)$ for significant differences between these fish effects.

\begin{tabular}{lclllrr}
\hline & Mean OUT & SD OUT & Mean IN & SD IN & Mean OUT - IN & $t$ test $p$ \\
\hline Day 14 & & & & & & \\
$\quad$ Total algae & 0.86 & 0.64 & 1.91 & 1.19 & -1.05 & $<0.01$ \\
Cryptomonads & 1.64 & 0.69 & 0.42 & 1.53 & 1.21 & $<0.01$ \\
Cyanobacteria & 2.91 & 0.98 & 3.83 & 1.87 & -0.92 & 0.14 \\
Chlorophytes & 0.27 & 0.66 & 0.95 & 0.97 & -0.68 & $<0.01$ \\
Diatoms & -0.93 & 1.35 & 1.26 & 1.61 & -2.18 & $<0.01$ \\
Day 28 & & & & & & $<0.01$ \\
Total algae & 1.66 & 0.60 & 0.82 & 0.61 & 0.84 & 0.01 \\
Cryptomonads & 2.14 & 1.42 & 1.13 & 1.20 & 1.01 & 0.31 \\
Cyanobacteria & 3.73 & 0.78 & 3.48 & 0.36 & 0.25 & 0.43 \\
Chlorophytes & 0.35 & 0.44 & 0.56 & 0.69 & -0.21 & 0.02 \\
Diatoms & 0.20 & 1.36 & 1.69 & 2.10 & -1.49 & \\
\hline
\end{tabular}

these two mechanisms suggested that nutrient recycling by fish can have stronger effects on phytoplankton communities than nutrient recycling by zooplankton (Vanni and Layne 1997). However, the relative importance of nutrient recycling by fish and zooplankton depends, among other things, on their relative biomass (Schindler et al. 1996).

Although we did not measure nutrient recycling rates in our experiment, our results suggest that increased zooplankton excretion was probably more important than direct excretion by fish because zooplankton biomass was higher than the fish biomass in the fish treatment. The biomass of fish stocked in our $3-\mathrm{m}^{3}$ enclosures was approximately $6 \mathrm{~g}$ dry weight, while the total biomass of zooplankton was about 9-12 g dry weight in the enclosures with fish and 3$4.5 \mathrm{~g}$ dry weight in the enclosures without fish. As expected from body size differences, zooplankton have a higher nutrient release rate per unit of biomass than fish, and we have shown in a previous study (Attayde and Hansson 1999) that the mass-specific nutrient release rates of zooplankton (Daphnia magna) are about 10 times those of $1+$ fish (Rutilus rutilus). Therefore, increased nutrient excretion by zooplankton might have accounted for most of the fishmediated nutrient recycling effects on phytoplankton in our experiment.

Finally, it should be noted that most studies that have investigated the effects of planktivorous fish on phytoplankton and zooplankton communities have been conducted in enclosures that were isolated from the sediment. However, many planktivorous fish, including our fish species P. fluviatilis, can feed on benthic/littoral resources and excrete nutrients in the pelagic zone, providing a net source of "new" nutrients to phytoplankton (Schindler et al. 1996; Vanni 1996; Schaus and Vanni 2000). Although our enclosures were also closed to the sediment, fish were fed benthic prey (chironomids) and thereby stimulated phytoplankton by releasing "new" nutrients into the enclosures. In doing so, fish may indirectly benefit zooplankton above and beyond any potential negative effects of their zooplanktivory (Attayde and Hansson 2001). Indeed, in our study, total zooplankton biomass increased in the presence of fish, partly due to this positive indirect effect of fish excretion but also due to a compensatory increase in small zooplankton biomass following reduction of larger competitively superior zooplankton.

By increasing total zooplankton biomass, planktivorous fish might have a positive effect on phytoplankton by increasing zooplankton nutrient recycling but also a negative effect by increasing zooplankton grazing. Conversely, the opposite effects would be expected when planktivorous fish reduce total zooplankton biomass (Ramcharan et al. 1996). Therefore, how phytoplankton will respond to fish should depend on the relative strength of the different mechanisms by which fish can affect phytoplankton and on how total zooplankton biomass responds to fish.

In conclusion, we have provided experimental evidence supporting the hypothesis that fish-mediated nutrient recycling has important effects on phytoplankton community structure. In particular, we have demonstrated that most of the positive effects of planktivorous fish on cyanobacteria and chlorophytes were due to nutrient recycling effects mediated by fish, most likely due to increased nutrient recycling by zooplankton in the presence of fish. The strength and direction of the phytoplankton response to fish are highly variable, and a major challenge to aquatic food web ecologists is understanding why this response is so variable (Brett and Goldman 1996). By quantifying the relative importance of the different mechanisms by which fish can affect phytoplankton under different environmental conditions, aquatic ecologists would better understand and predict the phytoplankton response to fish.

\section{Acknowledgments}

The Brazilian Government, through CAPES (Postgraduate Federal Agency), awarded a Ph.D. grant to J.L.A. and financed this research. Funding was also provided by the Swedish Foundation for International Cooperation in Research and Higher Education (STINT) to J.L.A. and by the Swedish Natural Science Research Council (NFR) to L.-A.H. We thank Michael Vanni and Sebastian Diehl for valuable comments on a previous draft of this paper. 


\section{References}

Attayde, J.L., and Hansson, L.A. 1999. Effects of nutrient recycling by zooplankton and fish on phytoplankton communities. Oecologia, 121: 47-54.

Attayde, J.L., and Hansson, L.A. 2001. The relative importance of fish predation and excretion effects on planktonic communities. Limnol. Oceanogr. 46: 1001-1012.

Bottrell, H.H., Duncan, A., Gliwicz, Z.M., Grygierek, E., Herzig, A., Hillbricht-Ilkowska, A., Kurasawa, H., Larsson, P., and Weglenska, T. 1976. A review of some problems in zooplankton production studies. Norw. J. Zool. 24: 419-456.

Braband, A., Faafeng, B.A., and Nilsen, J.P.M. 1990. Relative importance of phosphorus supply to phytoplankton production: fish excretion versus external loading. Can. J. Fish. Aquat. Sci. 47: 364-372.

Brett, M.T., and Goldman, C.R. 1996. A meta-analysis of the freshwater trophic cascade. Proc. Natl. Acad. Sci. U.S.A. 93: $7723-7726$.

Carpenter, S.R., and Kitchell, J.F. (Editors). 1993. The trophic cascade in lakes. Cambridge University Press, Cambridge, U.K.

Crumpton, W. 1987. A simple and reliable method for making permanent mounts of phytoplankton for light and fluorescence microscopy. Limnol. Oceanogr. 32: 1154-1159.

Dumont, H.J., Van de Velde, I., and Dumont, S. 1975. The dry weight estimate of biomass in a selection of Cladocera, Copepoda and Rotifera from the plankton, peryphyton and benthos of continental waters. Oecologia, 19: 75-97.

Gliwicz, Z.M., and Pijanowska, J. 1989. The role of predation in zooplankton succession. In Plankton ecology: succession in plankton communities. Edited by U. Sommer. Springer-Verlag, Berlin. pp. 253-296.

Gulati, R.D., Lammens, E.H.R.R., Meijer, M.-L., and VanDonk, E. (Editors). 1990. Biomanipulation tool for water management. Kluwer, Dordrecht, The Netherlands.

Hanson, J.M., and Leggett, W.C. 1982. Empirical prediction of fish biomass and yield. Can. J. Fish. Aquat. Sci. 39: 257-263.

Hansson, L.-A., and Bergman, E. (Editors). 1999. Nutrient reduction and biomanipulation as tools to improve water quality: the Lake Ringsjön story. Kluwer, Dordrecht, The Netherlands.

Hansson, L.-A., Annadotter, H., Bergman, E., Hamrin, S.F., Jeppesen, E., Kairesalo, T., Luokkanen, E., Nilsson, P.-A., Sondergaard, M., and Strand, J. 1998. Biomanipulation as an application of food-chain theory: constraints, synthesis, and recommendations for temperate lakes. Ecosystems, 1: 558-574.

Lamarra, V.A., Jr. 1975. Digestive activities of carp as a major contributor to the nutrient loading of lakes. Verh. Int. Ver. Limnol. 19: $2461-2468$.

Lazzaro, X. 1987. A review of planktivorous fishes: their evolution, feeding behaviours, selectivities and impacts. Hydrobiologia, 146: 97-167.

Osenberg, C.W., Sarnelle, O., and Cooper, S.D. 1997. Effect size in ecological experiments: the application of biological models in meta-analysis. Am. Nat. 150: 798-812.

Persson, A. 1997. Phosphorus release by fish in relation to external and internal load in a eutrophic lake. Limnol. Oceanogr. 42: 577-583.

Ramcharan, C.W., France, R.L., and McQueen, D.J. 1996. Multiple effects of planktivorous fish on algae through a pelagic trophic cascade. Can. J. Fish. Aquat. Sci. 53: 2819-2828.

Reinertsen, H., Jensen, A., Langeland, A., and Olsen, Y. 1986 Al- gal competition for phosphorus: the influence of zooplankton and fish. Can. J. Fish. Aquat. Sci. 43: 1135-1141.

Reinertsen, H., Jensen, A., Koksvick, J.I., Langeland, A., and Olsen, Y. 1990. Effects of fish removal on the limnetic ecosystem of an eutrophied lake. Can. J. Fish. Aquat. Sci. 47: 166173.

Romare, P., Bergman, E., and Hansson, L.-A. 1999. The impact of larval and juvenile fish on zooplankton and algal dynamics. Limnol. Oceanogr. 44: 1655-1666.

Schaus, M.H., and Vanni, M.J. 2000. Effects of gizzard shad on phytoplankton and nutrient dynamics: role of sediment feeding and fish size. Ecology, 81: 1701-1719.

Schindler, D.E. 1992. Nutrient regeneration by sockeye salmon (Oncorhynchus nerka) fry and subsequent effects on zooplankton and phytoplankton. Can. J. Fish. Aquat. Sci. 49: 2498-2506.

Schindler, D.E., and Eby, L.A. 1997. Stoichiometry of fishes and their prey: implications for nutrient recycling. Ecology, 78: 1816-1831.

Schindler, D.E., Carpenter, S.R., Cottingham, K.L., He, X., Hodgson, J.R., Kitchell, J.F., and Soranno, P.A. 1996. Food web structure and littoral zone coupling to pelagic trophic cascades. In Food webs: integration of patterns and dynamics. Edited by G.A. Polis and K.O. Winemiller. Chapman and Hall, New York. pp. 96-105.

Smith, V.H. 1983. Low nitrogen to phosphorus ratios favor dominance by bluegreen algae in lake phytoplankton. Science (Washington, D.C.), 221: 669-671.

Sommer, U. 1989. The role of competition for resource. In Plankton ecology: succession in plankton communities. Edited by $\mathrm{U}$. Sommer. Springer-Verlag, Berlin. pp. 57-106.

Starling, F.L.R.M., and Rocha, A.J.A. 1990. Experimental study of the impacts of planktivorous fishes on plankton community and eutrophication of a tropical Brazilian reservoir. Hydrobiologia, 200/201: 581-591.

Sterner, R.W. 1989. The role of grazers in phytoplankton succession. In Plankton ecology: succession in plankton communities. Edited by U. Sommer. Springer-Verlag, Berlin. pp. 107-170.

Sterner, R.W., and Hessen, D.O. 1994. Algal nutrient limitation and the nutrition of aquatic herbivores. Annu. Rev. Ecol. Syst. 25: $1-29$.

Sterner, R.W., Elser, J.J., and Hessen, D.O. 1992. Stoichiometric relationships among producers, consumers and nutrient cycling in pelagic ecosystems. Biogeochemistry, 17: 49-67.

Threlkeld, S.T. 1987. Experimental evaluation of trophic-cascade and nutrient-mediated effects of planktivorous fish on plankton community structure. In Predation: direct and indirect impacts on aquatic communities. Edited by W.C. Kerfoot and A. Sih. University Press of New England, Hanover, N.H. pp. 161-173.

Tikkanen, T., and Willén, T. 1992. Växtplanktonflora. Naturvardsverket. (In Swedish. Swedish Environmental Protection Agency.) Stockholm.

Vanni, M.J. 1996. Nutrient transport and recycling by consumers in lake food webs: implications for algal communities. In Food webs: integration of patterns and dynamics. Edited by G.A. Polis and K.O. Winemiller. Chapman and Hall, New York. pp. 81-95.

Vanni, M.J., and Findlay, D.L. 1990. Trophic cascade and phytoplankton community structure. Ecology, 71: 921-937.

Vanni, M.J., and Layne, C.D. 1997. Nutrient recycling and herbivory as mechanisms in the "top-down" effect of fish on algae in lakes. Ecology, 78: 21-40. 